J. Clin. Chem. Clin. Biochem.

Vol. 15, 1977, pp. 217-220

\title{
Kinetic Determination of Glucose Concentrations with Glucose Dehydrogenase
}

\author{
By H. Rindfrey, R. Helger and H. Lang \\ Biochemical Research E. Merck Darmstadt
}

(Received August 6/November 19, 1976)

Summary: A manual version and mechanized versions for several types of analyzers are described for the kinetic determination of glucose with glucose dehydrogenase. Results of glucose determinations with and without deproteinization of samples are discussed. The correlation of results with the hexokinase method is shown.

\section{Kinetische Glucose-Bestimmung mit Glucose-Dehydrogenase}

Zusammenfassung: Für die kinetische Glucose-Bestimmung mit Glucose-Dehydrogenase werden eine manuelle Version und mechanisierte Versionen für verschiedene Analysengeräte vorgestellt. Die Ergebnisse der Durchführung mit und ohne Enteiweißung sowie die Korrelation der Ergebnisse mit denen der Hexokinase-Methode werden mitgeteilt.

\section{Introduction}

Glucose dehydrogenase ( $\beta$ - $D$-glucose: $\mathrm{NAD}(\mathrm{P})^{+}-1$-oxidoreductase; EC 1.1.1.47) catalyses the dehydrogenation of $\beta$ - $D$-glucose to $D$-gluconolactone, whereby hydrogen is transferred either to NAD ${ }^{+}$or NADP. The amount of reduced coenzyme formed during the reaction is proportional to the glucose concentration. The enzyme isolated from the Bacillus megaterium mutant M 1286 is specific for the purpose of glucose determinations in body fluids $(1,2)$. To prevent the reaction velocity being limited by the mutarotation reaction, mutarotase (aldose-1-epimerase; EC 5.1.3.3) is added to the reagent.

Using catalytic concentrations of $9 \mathrm{kU} / 1$ glucose dehydrogenase and $0.2 \mathrm{kU} / 1$ mutarotase in the test solution the reaction is completed within 3 to 7 minutes, depending on the glucose concentration. In the end point version of the test the NADH concentration is measured by the absorbance difference of the test against a reagent blank. To eliminate errors caused by different absorbance of samples, deproteinization is necessary in end point methods. Manual as well as mechanized methods could be performed much more easily if this step were eliminated. Also for full utilization of the capacity of mechanized equipment the determination should be performed without depro: teinization. One way to eliminate the influence of different sample blank absorbance values is to use the reaction rate as an indicator for the substrate concentration. Because of the one step mechanism of the glucose dehydrogenase reaction it seemed possible to modify the reaction in such a way that the reaction rate can be measured kinetically.

Some variants of kinetic determinations of glucose concentrations have already been published. MüllerMatthesius (3) proposed a manual method, which, however, uses competitive enzyme inhibitors to achieve sufficient linearity of the reaction. The same linearity can be achieved by reduction of the catalytic concentration of the enzyme in the reaction mixture. Keller et al. $(4,5)$ published a mechanized method on a LKB reaction rate analyzer equipped with a special kinetic computer permitting continuous monitoring of the reaction during $5 \mathrm{~s}$ after a short lag time. Using $7 \mathrm{kU} / 1$ glucose dehydrogenase in the reaction mixture a satisfactory relation of absorbance change to glucose concentrations up to $22.2 \mathrm{mmol} / \mathrm{l}$ resulted. Lutz \& Flückiger (6) described a kinetic method for the ENI Gemsaec Fast Analyzer. These authors were able to measure glucose concentrations up to $55.5 \mathrm{mmol} / \mathrm{l}$ using a catalytic concentration of glucose dehydrogenase of $0.3 \mathrm{kU} / 1$ reaction solution. This was achieved by changes in the computer program of the analyzer. The nonlinearity of the calibration curve is corrected by a factor calculated from glucose standard curves. These methods demand either special equipment or special evaluation methods, which are not available at the time being.

In this paper we show, that with suitable modifications of reaction conditions and use of routine measuring 
equipment kinetic measurement of glucose concentrations using glucose dehydrogenase is possible with good precision and accuracy.

\section{Reagents and Methods}

\section{Reagents}

Glucose dehydrogenase: Merck, activity $38 \mathrm{U} / \mathrm{mg}$ of dry weight, specific activity $105 \mathrm{U} / \mathrm{mg}$ protein. NAD: Merck No. 24542. Tris-phosphate buffer $\mathrm{pH} 7.0: 0.35 \mathrm{~mol} / \mathrm{l}$ Tris $+0.40 \mathrm{~mol} / \mathrm{l}$ $\mathrm{NaH}_{2} \mathrm{PO}_{4}$. Tris-phosphate buffer $\mathrm{pH}$ 7.8:

$0.1 \mathrm{~mol} / 1$ Tris $+0.1 \mathrm{~mol} / 1 \mathrm{KH}_{2} \mathrm{PO}_{4}$. Hexokinase method: Boehringer Mannheim No. 15931.

\section{Methods}

Manual method for deproteinized samples: $0,7 \mathrm{kU} / 1$ of glucose dehydrogenase in Tris buffer $\mathrm{pH} \mathrm{7.8,} \mathrm{containing} 2.6 \mathrm{mmol} / 1$ NAD. The test is performed on an Eppendorf photometer with chart strip recorder, chart speed $1 \mathrm{~cm} /$ minute. $2.0 \mathrm{ml}$ reaction solution $\left(25^{\circ} \mathrm{C}\right)$ and $0.5 \mathrm{ml}$ deproteinized supernatant are mixed. After $30 \mathrm{~s}$ recording of the absorbance change at 334,340 or $366 \mathrm{~nm}$ is started. For evaluation a tangent is drawn onto the linear part of the recording and $\Delta A / t$ is determined from this line, see figure 1 . Glucose concentrations are calculated with the aid of a glucose standard solution, which is treated and analyzed in the same way as the sample.

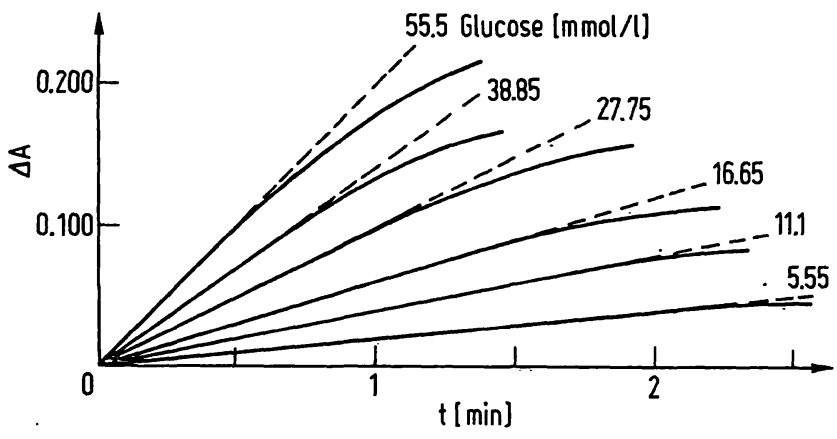

Fig. 1. Absorbance recordings of the kinetic glucose dehydrogenase method.

Manual procedure, see text.

Tab. 1. Scheme for kinetic glucose determination on mechanized analyzers.

Reagents see text.

\begin{tabular}{lll} 
& $\begin{array}{l}\text { LKB } \\
\text { Reaction } \\
\text { Rate Analyzer } \\
2086\end{array}$ & $\begin{array}{l}\text { Eppendorf } \\
\text { Enzyme Analyzer }\end{array}$ \\
\hline $\begin{array}{l}\text { Serum or plasma } \\
\text { alternatively: }\end{array}$ & $0.02 \mathrm{ml}$ & $0.01 \mathrm{ml}$ \\
$\begin{array}{l}\text { Deproteinized super- } \\
\text { natant }\end{array}$ & $0.20 \mathrm{ml}$ & $0.10 \mathrm{ml} \quad \ldots$ \\
$\begin{array}{l}\text { Reagent solution } \\
\text { Reag }\end{array}$ & $1.00 \mathrm{ml}$ & $0.50 \mathrm{ml}$
\end{tabular}

Equilibrate test mixture at temperature chosen

Starting reagent $\quad 0.10 \mathrm{ml} \quad 0.05 \mathrm{ml}$

Mix and measure at 334,340 or $365 \mathrm{~nm}$
Mechanized method for use on routine laboratory equipment (e. g. LKB Reaction Rate Analyzer 2086 or Eppendorf Enzyme Analyzer 5010/20): Serum and plasma can be analyzed directly, whereas whole blood must be deproteinized with perchlorate. The reaction is started by adding NAD solution. Reaction solution: $0.7 \mathrm{kU} / \mathrm{l}$ of glucose dehydrogenase in tris phosphate buffer $\mathrm{pH} 7.0$ and $22 \mathrm{mmol} / \mathrm{l}$ NAD. The analysis is performed according to table 1 . The absorbance is evaluated and the glucose concentration is calculated in the usual way with the aid of a glucose standard solution, which is treated and analyzed together with the sample. If analyzers with computers are used, the calculation factor is determined by analysing a glucose standard solution of known concentration.

\section{Results and Discussion}

\section{Manual Method}

By decreasing the ratio of enzyme cataly tic concentration to sample in the reaction mixture to about $1 / 10$ (in comparison to the end point method) the reaction velocity depends directly on the substrate concentration. Addition of mutarotase is not necessary. To obtain a sufficiently long (quasi)-linear part of the time vs. turnover curve, even at high glucose concentrations, the enzyme catalytic concentration must be as low as possible. On the other hand, to ensure the determination of low glucose concentrations with sufficient sensitivity, the enzyme catalytic concentration may not be decreased below a certain value.

Considering these limitations the proposed method is the optimal compromise. $\Delta \mathrm{A} / \mathrm{t}$ is linear for glucose concentrations up to $22.2 \mathrm{mmol} / 1$. The results for higher glucose concentrations are too low, the deviation at $55.5 \mathrm{mmol} / 1$ being minus $10 \%$. Comparative determinations on deproteinized samples with the kinetic method $(y)$ and the end point method $(x)$ give, with $\mathrm{N}=60, \overline{\mathrm{x}}=15.21 \mathrm{mmol} / 1, \overline{\mathrm{y}}=15.10 \mathrm{mmol} / \mathrm{l}$, $y=0.123+0.983 x, r=0.999$ and $s_{y \cdot x}= \pm 0.457$ $\mathrm{mmol} / \mathrm{l}$, a good correlation of results. At a concentration of $5.55 \mathrm{mmol} / 1$ a relative standard deviation of $\pm 4.4 \%$ $(n=20)$ is obtained.

\section{Mechanized Method}

With the method described the following results are obtained: Using the LKB Reaction Rate Analyzer and the Eppendorf Enzyme Analyzer the relation of $\Delta \mathrm{A} / \mathrm{t}$ vs. glucose concentration is linear up to $16.7 \mathrm{mmol} / \mathrm{l}$ glucose (fig. 2). The results for higher glucose concentrations are too low, the difference at $27.8 \mathrm{mmol} / 1$ being about $10 \%$. The accuracy of the method is verified by recovery experiments with 5-fold determinations using different concentrations of NBS standard reference glucose. In the range of 1.7 to $16.7 \mathrm{mmol} / \mathrm{l}$ glucose recovery is $98-102 \%$ of the expected value, relative standard deviation $\pm 2 \%$ (fig. 3). Analyses of several control sera with declared glucose concentrations from 4.3 to $17 \mathrm{mmol} / 1$ yield recoveries of 95 to $105 \%$ (tab. 2). Comparative determinations on deproteinized human sera with glucose con- 


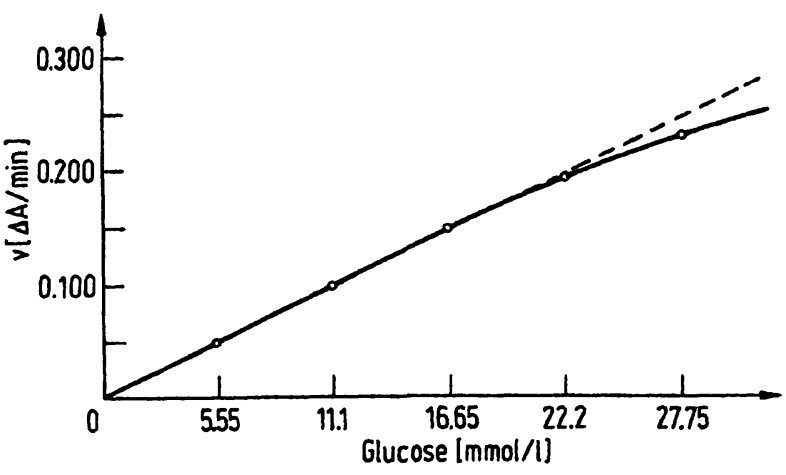

Fig. 2. Reaction rate vs. glucose concentration of the kinetic glucose dehydrogenase method on mechanized analyzers.

LKB Reaction Rate Analyzer and

Eppendorf Enzyme Analyzer.

Procedure according to table 1.

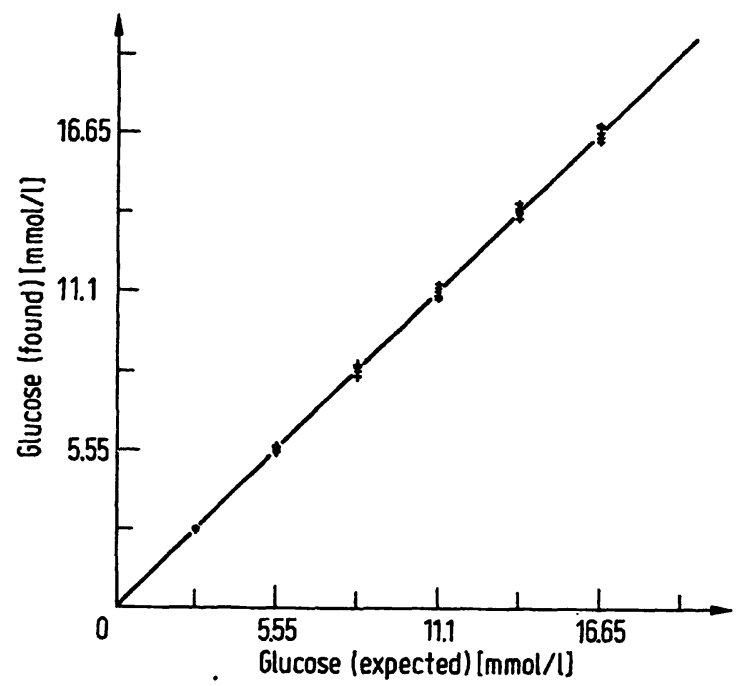

Fig. 3. Accuracy control of the kinetic glucose dehydrogenase method using NBS standard reference glucose.

Procedure according to table 1 .

$$
\begin{array}{lll}
\mathrm{n}=30 & \bar{x}=9.712 & \bar{y}=9.709 \\
\mathrm{y}=-0.017+1.001 \times & \mathrm{r}=0.999 & s_{y} \cdot \mathbf{x}= \pm 0.159
\end{array}
$$

Tab. 2. Glucose recovery experiments using control sera with the kinetic glucose dehydrogenase method.

\begin{tabular}{|c|c|c|c|c|c|}
\hline \multirow[t]{2}{*}{ Control serum } & \multirow{2}{*}{$\begin{array}{l}\text { Declared } \\
\text { concen- } \\
\text { tration } \\
{[\mathrm{mmol} / \mathrm{l}]}\end{array}$} & \multicolumn{4}{|c|}{$\begin{array}{ll}\text { Measured concentration }[\mathrm{mmol} / \mathrm{l}] \\
\text { without } & \text { with } \\
\text { deproteini- } & \text { deproteini= } \\
\text { zation } & \text { zation }\end{array}$} \\
\hline & & $\overline{\overline{\mathbf{x}}}$ & $\pm s$ & $\overline{\mathbf{x}}$ & $\pm s$ \\
\hline \multirow{7}{*}{$\begin{array}{l}\text { Monitrol } 1130 \mathrm{AB} \\
\text { Monitrol II } 33 \mathrm{AB} \\
\text { Pathotrol } 64 \mathrm{~A} \\
\text { Seronorm } 124 \\
\text { Versatol A } \\
\text { Alternate } \\
\text { Versatol A }\end{array}$} & 4.3 & 4.3 & 0.18 & 4 & 0.13 \\
\hline & 11.3 & 11.9 & 0.44 & 11.5 & 0.37 \\
\hline & 14.3 & 14.7 & 0.52 & 14.6 & 0.41 \\
\hline & 6.3 & 6.5 & 0.27 & 6.2 & 0.18 \\
\hline & 17 & 16.5 & 0.66 & 16.8 & 0.50 \\
\hline & & & & & \\
\hline & 11.4 & 11 & 0.41 & 11.2 & 0.32 \\
\hline
\end{tabular}

n $=\mathbf{3}$ for each experiment.

centrations from 3.3 to $16.7 \mathrm{mmol} / \mathrm{l}$ with the hexokinase method versus the kinetic glucose dehydrogenase method show a close agreement (fig. 4). The regression line is not significantly different from the value of 1.0 , the mean variation is $\pm 0.44 \mathrm{mmol} / \mathrm{l}$ glucose.

The results obtained by the kinetic glucose dehydrogenase method performed on deproteinized samples are not significantly different from those on samples without deproteinisation (fig. 5). The mean relative standard

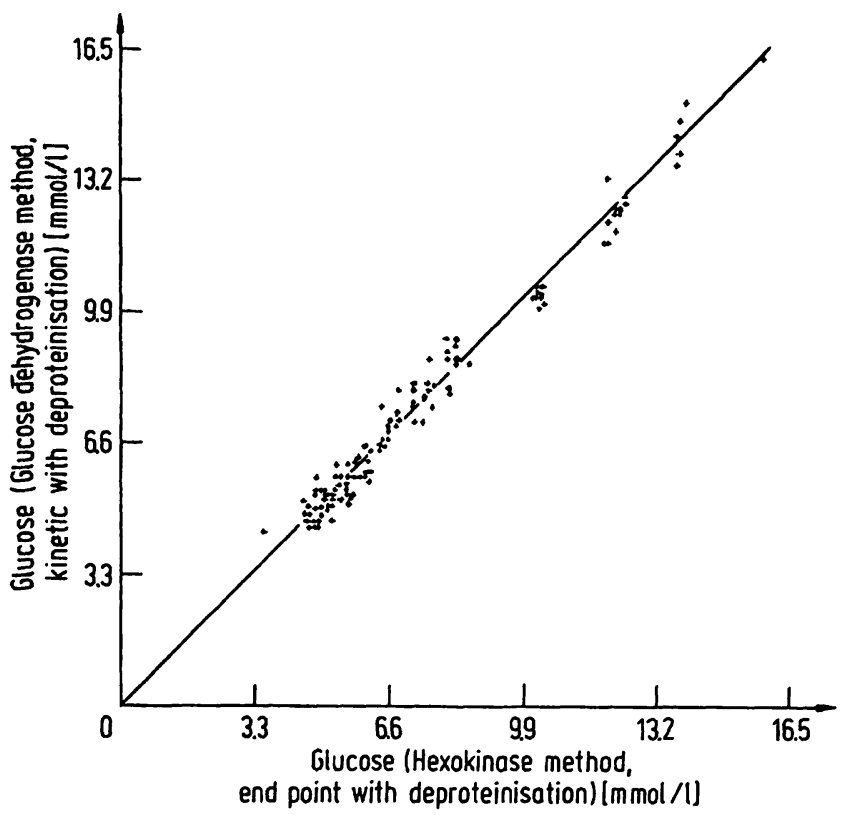

Fig. 4. Correlation of glucose determinations: Hexokinase method, end point version vs. glucose dehydrogenase method, kinetic version.

Glucose dehydrogenase method: procedure according to table 1.

$$
\begin{array}{lll}
n=171 & \bar{x}=7.33 & \bar{y}=7.61 \\
y=-0.005+1.041 \times & \mathbf{r}=0.987 & s_{y} \cdot x= \pm 0.439
\end{array}
$$

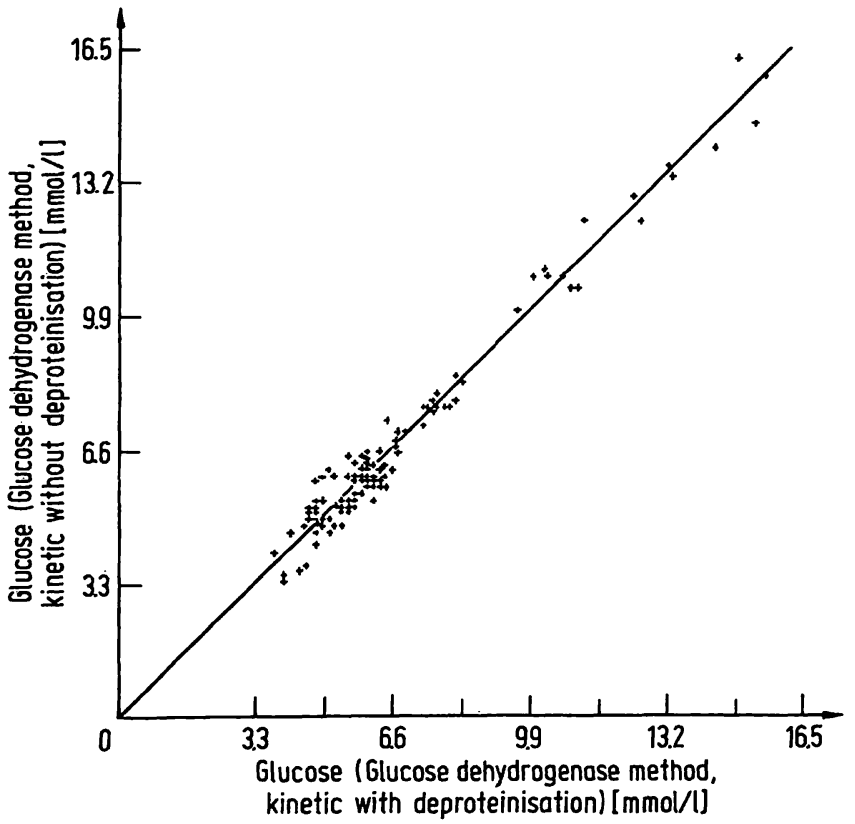

Fig. 5. Correlation of glucose determinations: kinetic glucose dehydrogenase methods with vs. without deproteinization.

Procedure according to table 1 .

$$
\begin{array}{lll}
\mathrm{n}=124 & \overline{\mathrm{x}}=6.83 & \bar{y}=6.94 \\
\mathrm{y}=-0.035+1.018 x & \mathrm{r}=0.976 & s_{y} \cdot \mathrm{x}= \pm 0.572
\end{array}
$$


deviation of the direct method is $\pm 4 \%$, and $\pm 2.8 \%$ for the method with deproteinisation.

Only slight modifications are necessary (e. g. starting the reaction by addition of sample) to adapt this method to the ENI Gemsaec fast analyzer. This analyzer offers several possibilities for the evaluation of kinetic reactions. For example, absorbance measurements at intervalls of $10 \mathrm{~s}$ permit virtual continuous monitoring of the reaction. The internal computer then fits a straight line to those points which are in a preset acceptance range (line $b$ in fig. 6). This kind of evaluation is fairly equivalent to the evaluation methods used by the LKB reaction rate analyzer and the Eppendorf Enzyme

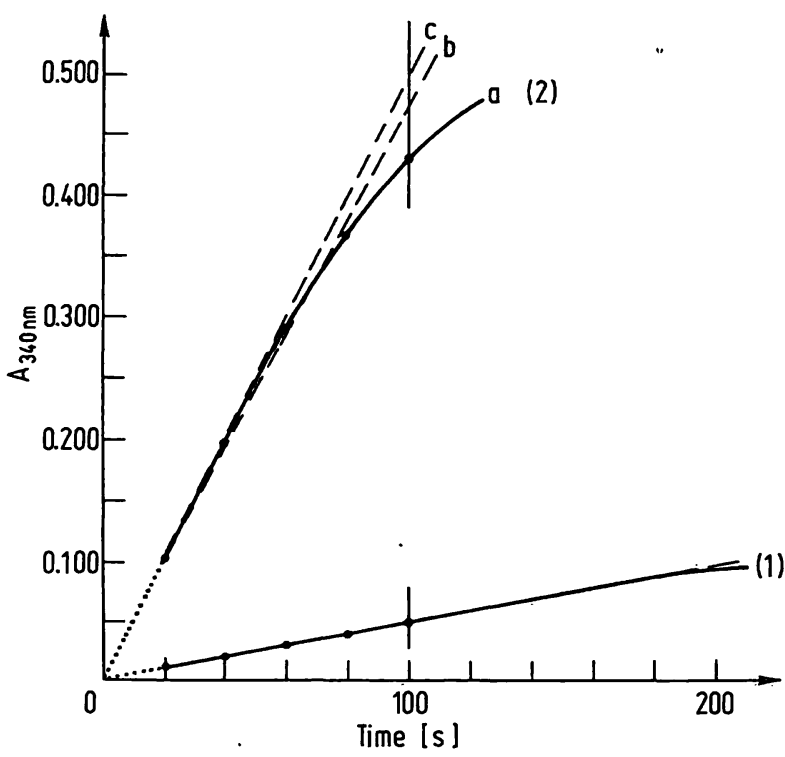

Fig. 6. Kinetic measurement of glucose concentrations with glucose dehydrogenase on the ENI Gemsaec analyzer; evalutation of results.

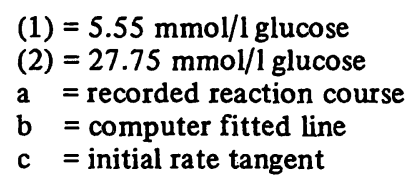

\section{References}

1. Banauch, D., Brümmer, W., Ebeling, W., Metz, H., Rindfrey, H., Lang, H., Leybold, K. \& Rick, W. (1975), this J. 13, 101-107.

2. Pauly, H. E. \& Pfleiderer, G. (1975), Hoppe-Seyler's.Z. Physiol. Chem. 356, 1613-1623.

3. Müller-Matthesius, R. (1975), this J. 13, 187-189.
Analyzer. The resulting linearity is therefore directly comparable to that found on these analyzers.

Even better results on the Gemsaec analyzer are obtained by increasing the enzyme catalytic concentration to $5 \mathrm{kU} / 1$ and by calculation of the glucose concentrations on the basis of 2-point kinetic measuremients. The first reading is taken $10 \mathrm{~s}$ after mixing and the second reading $90 \mathrm{~s}$ after the first one (fig. 7). If a deviation of about $\pm 5 \%$ in the higher concentration range is accepted, the calibration curve is linear up to $55.5 \mathrm{mmol} / \mathrm{l}$ glucose. This effect can be explained in such a way that the reaction conditions approach the conditions of the end point method.

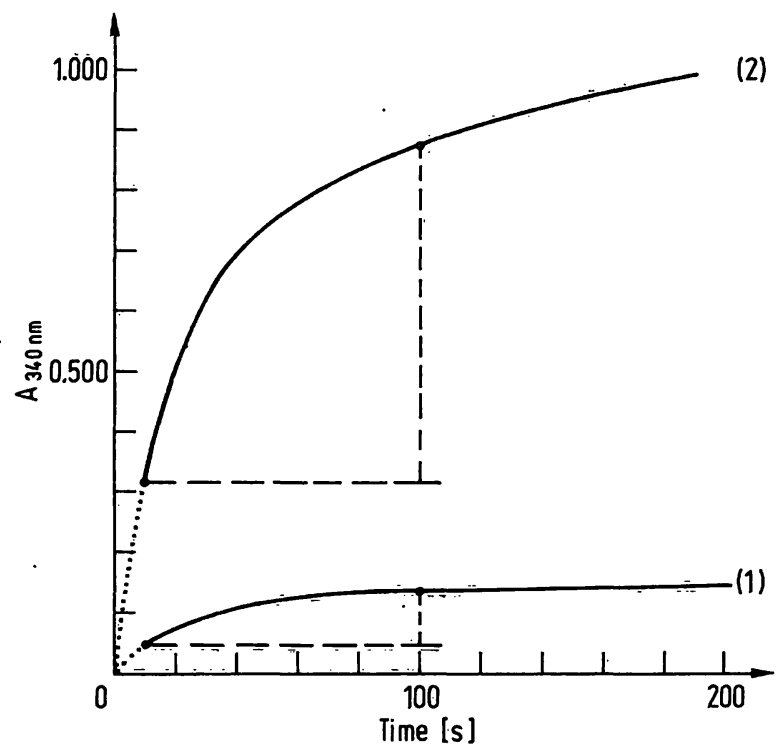

Fig. 7. Two point measurement of glucose concentrations with glucose dehydrogenase on the ENI Gemsaec analyžer; evaluation of results.

(1) $=5.55 \mathrm{mmol} / \mathrm{l}$ glucose

(2) $=27.75 \mathrm{mmol} / \mathrm{l}$ glucose

\section{Acknowlẹgement}

The skilful technical assistance of Miss $R$. Jammès and Mir. $F$. Sondheimer is greatly appreciated.
4. Keller, H., Faust, U. \& Becker, J. (1973), Chem. Rundsch. $26,24-29$.

5. Keller, H. \& Wolf, V. (1976), this J. 14, 27-30.

6. Lutz, R. A. \& Flückiger, J. (1975), Clin. Chem. 21, $1372-1377$
Dr. H. Lang

Biochemical Research E. Merck P.O. Box 4119

D-6100 Darmstadt 2 